\section{Rooting out the wine plague}

\section{Phylloxera: How Wine was Saved for the World \\ by Christy Campbell \\ HarperCollins: 2004. 314 pp. £17.99 \\ Jeffrey Granett}

Grape phylloxera (Daktulosphaira vitifoliae Fitch) is an aphid-like insect native to North America that devastated European viticulture in the nineteenth century. On native American grapevines, the insect initiates galls on expanding vine leaves and immature roots, doing little harm to the plants' overall fitness. But when it finds itself on European vines (Vitis vinifera), its populations develop on mature storage roots, disrupting their function and introducing myriad secondary fungal pathogens, ultimately killing the vines.

When the insect first arrived in France in the mid-nineteenth century, the damage it caused could not be attributed to it because it was essentially invisible, as it lived and fed below ground. This was the last place a grape grower of the time would look for a cause of symptoms observed above ground. In addition, phylloxera are tiny (less than a millimetre in length) and populations vanish on dying vines.

Once the cause of the problem was discovered, there was no apparent solution. A large cash prize was offered for a cure and many off-the-wall ideas were tested, but the prize was never awarded. Removing and burning infested vines did not slow the spread. Carbon bisulphide fumigation of

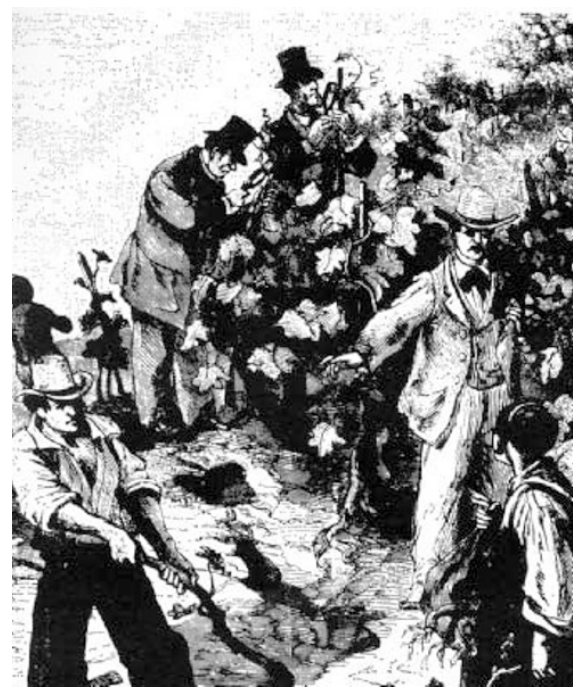

Phylloxera ravaged Europe's vines until the use of American rootstocks led to French resistance.

infested vines helped, but was not economically viable in the long term. The vineyards were eventually saved by using phylloxeraresistant native American vines, not as direct fruit producers (the taste of wine from American grape species was unacceptable), but as rootstocks. The technology for this was optimized for vineyard locations and soil types, and has been amazingly successful ever since.

This story is dramatized in Phylloxera: How Wine was Saved for the World from the perspective of a wine lover. Christy Campbell focuses on how the people involved both in Europe and the United States went about solving the phylloxera problem. Science was clearly important, but so were the feelings and biases of the scientists and social progressives, the traditionalist wine growers,

\section{Reissued classics}

\section{The Sea Around Us}

by Rachel Carson

Oxford University Press, \$45

Although Rachel Carson is best remembered as

the author of Silent Spring, it was this natural

history of the oceans that established her reputation as a science writer. The book was first published in 1951, so Carson was not able to include the subsequent discoveries of seafloor spreading and deep-ocean exploration. These events are included here in an introduction by Robert Ballard and an afterword by Brian Skinner.

America's Forgotten Pandemic: The Influenza of 1918

by Alfred W. Crosby

Cambridge University Press, £42.50 (hbk), $£ 15.99 \mathrm{pbk}$

With bird flu and SARS regularly in the news, publication of this second edition of Alfred Crosby's account of the American pandemic of Spanish Influenza is very timely. In 1918-19, Spanish flu killed more people across the world than the World War that preceded it. Since its first publication in 1976, this account of the devastation wrought by this disease has taken on more contemporary relevance, as the author reminds us in a new introduction.

\section{The Piltdown Forgery}

by J. S. Weiner

Oxford University Press, £8.99, \$14.95

The discovery in the early 1900 s of Piltdown Man, the fossilized remains of an ape-like human, was greeted by much excitement. But a re-examination of the fossils in the 1950s revealed them to be forgeries. Joseph Weiner was one of three scientists who exposed this hoax, and his fascinating detective story, first published in 1995, remains the definitive account of the affair. As Chris Stringer points out in a new introduction and afterword, the identity of the hoaxer(s) is still not certain. those out to make money, and the wine lovers, including some who held positions of authority. In this context, the role of the scientists was not only to devise methods and test ideas, but to convince the rest of the stakeholders of the need for particular points of view and courses of action. Campbell tells how the key scientific players - Leó Laliman, Jules-Émile Planchon, Louis Vialla and others - played the role of propagandists, sometimes successfully, sometimes not. Their's was a science that clearly required subjective as well as objective thought.

This approach to the phylloxera story is as important for the scientist to understand as it is for the layman. We must realize that even the most objective applied research is rarely convincing enough to find immediate utility without a lot of subjective interpretation, value judgements and soul searching. Campbell exemplifies this conflict with a lengthy description of the difficulties that the scientists faced in gaining acceptance of American vines as the solution to the phylloxera problem. American vines brought phylloxera to France in the first place, so how could their use be encouraged without increasing the risk of further phylloxera infestations and possibly opening up French viticulture to new, yet undiscovered scourges? How could the unacceptable 'foxy' taste of the American grapes not find its way into French wine, even if the American vines were used only as rootstocks? How can a noble French wine be truly noble and French if it owes a debt to wild, uncivilized American grapes?

The definitive answers to these questions had to wait until the rootstocks had been in the ground and producing wine for a decade or more. The first users of the rootstock technology did not have enough facts - they needed to be convinced by the propaganda. The story as told by Campbell has a colourful array of heroes and charlatans, and is neither completely linear nor holistic — but nor was the phylloxera problem caused or solved completely from the top down or bottom up. But it is an exciting, compelling tale. Campbell's short description of possible uses for genetic engineering in his concluding section make it clear that such stories are not over even after you put the book down. For English readers who would like more information, George Ordish's The Great Wine Blight provides more science, as do viticultural histories such as Harry Paul's Science, Vine, and Wine in Modern France (reviewed in Nature 387, 670-671; 1997).

Campbell's book is a fairly easy read, although the timeline gets a bit tangled occasionally. Its focus is on people solving a problem, but it provides enough science for the general reader to understand the controversies and the logic of the eventual outcome. Jeffrey Granett is in the Entomology Department, University of California, Davis, California 95616, USA. 